POLISH POLITICAL SCIENCE

VOL XXXIX 2010

PL ISSN 0208-7375

ARTICLES

\title{
DIPLOMACY IN THE POSTMODERNITY
}

\author{
by Teresa Łoś-Nowak
}

Considerations devoted to postmodern diplomacy should be preceded by reflection on the phenomenon of postmodernity, because everything, what it expresses, creates some kind of depth of causative powers of changes, which affect diplomacy, traditionally connected with state, its foreign policy, raison d'état, reasons and interests, to realisation of which it should serve. The diplomat's mandate is still a mandate coming from state, which they represent and on behalf of which they act. However, on the other hand, diplomatic functions are more and more often attributed to non-state subjects, which have different objectives and tasks to accomplish.

So one can risk saying that diplomacy changes in the same way as postmodern international system, loosing slowly its state-centred character for the benefit of multicentricity. What is the postmodernity and what changes does it introduce to the model of traditional diplomacy?

Certainly, postmodernity is the sign of intellectual protest of researchers from beyond the circle of international relations, mainly philosophers, sociologists, often anthropologists, against enlightenment, scientific approach to the subject and research methods in this area. It is also the sign of distrust towards emphasised by the school of "traditionalists" the 
need of formulating clear, well-considered and verifiable research hypotheses, paradigmatic patterns of researches, precise language, characteristic for science and scientificity. Postmodernity is also research approach rejecting the possibility of creating neutral, objective theory of international relations, "arranged" statements, paradigms, models of behaviour in such a dynamic area as international relations.

Postmodernity as a premise of discourse in the political science, including international relations science, is also specific manifesto of scholars, who pay attention to its methodological weaknesses, i.a. due to displaying artificial, as they emphasise, assumptions about existence of borders between social and humane disciplines. They treat them as harmful for a researcher, because they hamper, sometimes even make it impossible, to understand the world. ${ }^{1}$

Cognition - what is emphasised in almost all theories developed within the framework of post-positivist debate - doesn't know borders, it is continuous process, confrontation of thoughts and knowledge about cognition, and mechanisms of recognition. ${ }^{2}$ The quality of research results is determined by ontological and epistemological nature of cognition. Getting to know social reality is possible, but it is unusually complicated process, mainly because "examined social reality doesn't project itself isomorphically in researcher's awareness. It is usually "unknown", "synonym of chaos of unimaginable multiplicity of phenomena, which a researcher attempts to get to know and put in order..."3 So as long as

\footnotetext{
${ }^{1}$ C. Reus-Smith, The Moral Purpose of the State: Culture, Social Identity and Institutional Rationality in International Relations Princeton 1999, R.B. J. Walker, Inside/Outside: International Relations as Political Theory, Cambridge, A. Linklater, Beyond Realism and Marxism: Critical Theory of International Relations, London 1990, Sm. Smith, Positivism and Beyond, [in:] S. Smith, K. Booth and M. Zalewski (eds.), International Political Theory: Positivism and Beyond, Cambridge 1996, A. Wendt, Społeczna teoria stosunków międzynarodowych, translation: W. Derczyński, Warszawa 2008.

2 R.B.J. Walker, Inside/Outside: International relations and Political Theory, Cambridge, A. Linklater, Beyond Realism and Marxism: Critical Theory of International Relations, London 1990, S. Smith, Positivism and Beyond, [in:] S. Smith, K. Booth and M. Zalewski (eds.), International Political Theory: Positivism and Beyond, Cambridge 1996.

3 B. Krauz-Mozer, Metodologia politologii w perspektywie pluralistycznej (Methodology of political science in the pluralist prospect), [in:] K.A. Wojtaszczyk, A. Mirska, Demokra-
} 
researchers won't make themselves "scientifically" certain of opportunities of getting to know in time social or international reality, being somehow beyond it, results of their research will be doubtful.

One could agree with such an argumentation of post-positivist researchers, although their scientific approach has numerous weaknesses. First of all, in the process of cognition these researchers use language and tools present today in the international relations science. Secondly, in their manifested autoreflexivity they formulate statements as arbitrary as researchers of classic and neoclassic trends. This weakens postmodernist thesis, saying that each theory is always partial. If so, also theories created by them are partial. Rejecting or questioning the ability of human mind to get to know the world, so denying the "quality" of this product, they are entrapped in scientific nihilism. Assuming a priori, that in social sciences there is nothing like objective research or methodological correctness, if one accepts as an axiom that social, political or cultural reality is always an interpretation of a researcher dealing with international relations, that it accounts for manifestation of their knowledge about "examined" reality, one can complain about its little usefulness at all, especially on the explanatory level. This seems irrational.

Postmodernity as a component of international relations science is in opposition to traditional research trends and paradigms, especially realism, but also to modernism, accused of the lack of autoreflexivity, distance towards "rational" understanding of this world for the benefit of its "reading" "Postmodernity tries to expose this, what is considered by "enlightened" mind as objective data that is "rational or historical necessity, objective nature laws discovered by science or divine orders." 4 At the same time, researchers especially with philosophical, but also sociological or psychological background, as for example R. Cox, S. Smith, A. Gidens,

tyczna Polska w globalizującym się świecie (Democratic Poland in globalised world), I AllPoland Congress of Political Science, Warszawa 2009, p. 156.

4 A. Wójcik, Rozumienie kategorii Power (potęgi, sity, władzy) w myśli ponowoczesnej (Understanding the category of Power in the postmodern thought), „International Relations" 2009, No. 1-2, p. 53. 
A. Linklater ${ }^{5}$, due to their metaphorical and based on hermeneutical understanding of a process of cognition language, hamper process of cognition and understanding problems located in the field of international relations. Metaphors - as W. Kostecki rightly notices in the essay on metaphors in politics and ideology - can do a lot."They help to understand and explain. They disclose assumptions, which we would often prefer to hide. They direct our thinking, shape attitudes and actions, reflect collected experiences and way of perceiving the world." 6 However, they can't replace scientific precision in thinking, formulating clear codes of behaviour etc., premises of science and scientificity.

Next interparadigmatic discourse, as previous ones, is connected with different understanding of a function of international relations science and methodological discussion carried on for almost 30 years in this disciple. There are continuously returning questions about politics in the postmodern world, its specificity and way of realisation, instruments used by international relations participants, quality of methods dominating in international relations. There are returning discussions on the quality of postmodern state, on how it should function in the postmodernity, how its foreign service should work, how it should carry out its duties to others, what ethics of war and war ethics mean, what forms of non-state community's organisation are there, what is important in a process of formulating and realising foreign policy of a state and its diplomatic activities, what is expressed by non-territorial subjects.

In this context, current and extremely important becomes the problem of effectiveness of diplomacy and state's foreign service, as well as its abilities to rise to challenges given by the postmodern world. One often hears, that modern Leviathan isn't properly prepared and equipped with appropriate instruments to perform duties imposed by the postmodernity, with such huge actors as transnational corporations, economic-social

5 R. Cox, Towards a post-hegemonic conceptualization of World Order: Reflection on Relevance of Ibn Khaldun, [in:] J.N. Rosenau, E.O. Czempiel, Governance without Government: Order and Change in World Politics, Cambridge 1992, p. 132/133.

${ }^{6}$ W. Kostecki, O metaforach, polityce i politologii, [in:] „Metafory polityki 3”, Warszawa 2005, p. 23. 
agendas with scope of activities broader than particular countries, with deepening interdependence. In this context, there is important question about the role played in this process by traditionally shaped diplomacy, how it changes and on the strength of what factors. Certainly, diplomacy is changing on the great strength of external activity of subjects with quasistate or non-state attributes, with interests and preferences in relations with environments often totally different than these attributed to subjects organised territorially. Problem and challenge for researchers is the attempt of examining how traditional diplomacy is changing, what challenges it rises up to and what instruments it moves, in order to infix itself in the canon of postmodernity ${ }^{7}$.

Recently observed specific renaissance of interest in diplomacy, especially in "new" or "postmodern" diplomacy tends to reach out these problems, doubts, and researches. As in the case of every phenomenon or process, which description isn't fully possible with use of old methods or research tools, as in the case of diplomacy and evolution, new view seems to be necessary.

First and basic difficulty is the notion of "postmodern diplomacy" itself. Mainly because of moving centre of gravity in functions of diplomacy connected with sovereign state, political issues, economic or fuel diplomacy, military safety for the benefit of cultural and social safety or terrorist threats. Changes in the area of statements traditionally attributed to diplomacy concern also methods of activities being at the disposal of state and quasi-territorial subjects. Powerful weapons in hands of diplomats and others are new means of communication, new media, especially satellite television, blogs etc. They take problems traditionally solved in secluded place of studies out to broad international forum, solving them by methods often far from those recognised as diplomatic means. So one can advance a thesis, that dynamic development of means of international communication, newer and more accessible means of international and transboundary communication is one of the biggest symptoms of changes

\footnotetext{
7 R. Cox, Social Forces. States and World Orders. Beyond International Relations Theory, "Millennium" 1981, vol. 10, No. 2, p. 128.
} 
in the formula of diplomacy ${ }^{8}$, next to increasing number of non-state actors participating in politics and diplomacy.

\section{CLASSIC VERSUS POSTMODERN DIPLOMACY?}

One can assume, that observed nowadays allocation of authorities from the level of national state to the level of supranational structures, moving and concentration of relations from the inter states level to the regional, transboundary and global level, arouses specific consequences for its external function. These consequences involve not only process of formulating state's foreign policy, but also those people, who realise this policy, that is diplomats and diplomacy.

International system, defined as postmodern or - as M. Pietraś emphasises late-Westphalian - generates phenomena and processes, which not only have changed its structure, but also concentrated the "arena" of international politics, changed mechanisms of solving international problems, "demolished" the scale of their importance and urgency. Their constant presence in the international system seems to weaken state's ability to represent new social groups, non-territorial subjects and other participants of international relations, which emanation they are and which interests they realise. These new actors of world politics are sure of their natural need of representing social, economic, cultural and other subjects, identifying themselves with their objectives and philosophy of activities. They use methods often different from those used in diplomacy of the Westphalian model of international relations. Often they undermine state's legitimacy to represent them.

Slowly developing process of democratising international relations seems to indicate even the unit (or social group) as a bearer and exponent of specific individual reasons and interests or those of diverse groups and political communities. Recently such ones become subjects defined as quasi states, not having formal-legal sovereignty, with limited (or no)

\footnotetext{
8 Shaun Breslin, Beyond Diplomacy? UK Relations with China since 1997, "Political Studies Association" 2004, vol. 6, pp. 409-410.
} 
ability to represent their interests in the international community, not maintaining diplomatic relations, groups with unclear (network) level of organisation with great political-ideological aspirations and objectives, denying established international order and its value systems ${ }^{9}$. In the lateWestphalian international system, there becomes important legal-international and political-international problem, that is if and to what degree traditional diplomatic instrumentarium, regulations and international conventions regulating diplomatic relations can be transferred to activities of non-state participants of international relations.

In the postmodern world, where sovereignty evolves, international system becomes more and more complicated, economy becomes globalised, strategies of coexistence undergo dynamic changes, similarly as means, which elude control of classic sovereign, diplomacy in classic understanding of its essence may seem quite archaic and old-fashioned addition to the postmodern diplomacy, even "gunboats", "ping-pong", "cod", in which power or other form of violence replaces traditional diplomatic forms, suitable for relations on the state level for the benefit of non-territorial subjects. In the international system, where crossing territorial borders is not a problem, appeared new dimensions of diplomacy, like for example public diplomacy ${ }^{10}$, diplomacy of transnational corporations, diplomacy of the European Union, social diplomacy (broadly developed initially in the United States, United Kingdom and France), diplomacy of regional integration or global problems. Still open is antidiplomacy, with described by Der Derian methods, such as terror, spying, rape, war $^{11}$, perceived sometimes as a reverse of procedures and behaviour specific for diplomacy.

9 From these groups of international relations one should exclude Taiwan, West Sahara and Kosovo, recognised by most countries and often having developed diplomatic representation in capitals of many countries (e.g. Taiwan). More [in:] M. Kosienkowski, Quasi państwo w stosunkach międzynarodowych, „Stosunki Międzynarodowe” 2008, No. 3-4, pp. 151-163.

10 More about this topic, B. Ociepka, Dyplomacja publiczna, Wrocław 2008.

11 J. Der Derian, Antidiplomacy: Spies, Speed, Terror and War, Oxford Blackwell 1992. 
With such a diverse area of international activities, as well as rich arsenal of means and methods of activities at disposal of new subjects of international relations, there is still open the question about components creating "postmodern" or "new" diplomacy and criteria allowing for distinguishing classic (traditional) and "new" (postmodern) ${ }^{12}$ diplomacy. It is also worth to think for a while about what has left from classic diplomacy, which of its forms have undergone the greatest changes, which functions remained unchanged, which have been evolving, finally, how we consider the essence of diplomacy today, if its bearers are not only states and their representatives subjected to a discipline of the Convention on Diplomatic Relations from year 1961.

One should probably start from quite a nostalgic statement, that surrounded by the atmosphere of unusualness, elegance, mystery, but also secrecy, classic diplomacy has to coexist with other forms and ways of communication of states, quasi states, other political communities, nations, but also criminal organisations such as gangs, terrorist organisations, etc. The metaphor about a diplomat as an honest person, who lies in foreign country for the benefit of its ruler is only a metaphor, just like understanding its main objective and ways of accomplishing it. It means that the circle of diplomatic service subjects changes diametrically, just as objectives accomplished by them. Also the way of functioning of other subjects, such as states, is changing radically.

Modern diplomacy certainly doesn't mean "skilful" and "elegant" use of trick, chicanery and other ways "in the name of state's raison d'être and interests." Modern diplomat, no matter if it's a representative of state or other subject of international relations, is a knowing foreign language, cultural polymath. Expert-advisory functions of classic diplomats extort on their modern representatives high professionalism, precision in acting and responsibility free from inhibitions of Machiavellian motto, that the end justifies the means. Presenting diplomacy by philosophers-moralists as an old-Italian deity with two faces, turned to opposite sides, and loses

12 S. Murray introduces the third type of diplomacy, placed between classic and postmodern, it is called modern. More:

S. Murray, Consolidating the Gains Made in Diplomacy Studies: A Taxonomy, "International Studies Perspectives" 2008, vol. 9, p. 22. 
its morally ambiguous meaning. Janus's face of the then diplomacy seems to be exposed by the accessibility of information sources, their quick circulation, and great availability of the most modern methods of exposing "double" game of diplomats. What seems to be extremely important in the discourse on postmodern diplomacy is the phenomenon of postpoliticalness, which is attributed by postmodern researchers to modern diplomats and international relations.

Postpoliticalness can be understood here as the lack of manifestation of dictate and exclusion from political discourse of actors, who don't accept Western vision of the world, international order, dictate of Western values, their reasons, and interests. It is symbolised not only by business entities, with transnational connections and interests, which feel "too tight" in national borders, but also social organisations representing group interests, organisations symbolising different degrees and levels of integration, international communication institutes going far beyond functions of observers of international phenomena and processes. Amongst them are also organised social-political powers, which striv for realisation of their reasons and interests, demolish and break all regimes with diplomatic origin. These are organisations with the terrorist origin and such intentions.

So one can assume, that differences and similarities between the diplomacy specific for Westphalian and post-Westphalian model of international relations concerns several basic determinants. First, these are changes in the field of international relations participants, second, changes in the formula of diplomatic behaviour, kinds of reasons and interests, being followed by various participants of international relations in their international activities, finally, changes of relations in the set: state's foreign policy and foreign service, particularly diplomatic service.

Classic diplomacy is perceived as an activity aiming at accomplishment of objectives, set for them by foreign policy. It is state's tool, but the level of realising its interests and efficiency of activities ${ }^{13}$ depends on abilities of state authorities. Special phenomenon in the international system at the turn of 20th and 21st century was terrorism, setting for the diplomatic

13 J. Kleiner, The Inertia of Diplomacy, "Diplomacy and Statecraft” 2008, vol. 19, p. 327 and other. 
service tasks, to realisation of which it was usually unprepared. So we can assume, that new phenomena and developmental trends affect modern diplomacy, its institutional development, legal and international regulations, methods and means of activities with unusual power. However, on the other hand, independently on the fact, that diplomacy in the postmodernity changes its image, great changes occur in its functioning, it still adapts itself to new challenges, its modern message is still the same since states appeared. The complexity of evolution, to which it is subjected, consists in that its essence in consequent realisation of foreign policy. Only methods and means of its realisation change, as well as the model of diplomacy changes. "Opening" of the world and accessibility of knowledge about it to the highest degree influence the process of transformation, to which classic diplomacy is subjected.

\section{SUBJECTIVE-OBJECTIVE SYMPTOMS OF DIPLOMACY'S EVOLUTION}

If one assumes, that in short as diplomacy we understand official, formal activities of a state, conducted by properly prepared teams and institutions with solid structures, aiming at protecting state and its citizens' interests in the way of conducting negotiations, while obeying valid norms of international law, fulfilling diplomatic functions should be attributed to state representatives and institutions, which have at their disposal suitable human and organisational resources, and - what's more important - powers to represent state and its citizens. However, as I mentioned above, next to states there are also non-territorial actors, which activities in many areas of international life consist in the philosophy of Article 3 of the Convention on Diplomatic Relations from year 1961. Admittedly, it says about functions of state's emissary realised in hosting country, nevertheless practically each mentioned function infixes itself to tasks, which are to be realised by non-territorial actors. They also represent interests of their principals, conduct negotiations, get to know possibilities and conditions in a state, on which territory they act. Also the Convention on Special Missions from year 1969 perceives special missions as "missions represent- 
ing a state." But Convention from year 1975 about representation of states in their relations with international organisations introduces the system of diplomatic protection towards representatives of international organisations. Under the provision of Article 6 of Convention, their basic functions include "maintaining a bond between sending country and international organisation, conducting negotiations with an organisation [...] and supporting accomplishment of objectives and principles of organisation through cooperation with an organisation and within it." It is also worth to mention in this context the Protocol on the Privileges and Immunities of the European Communities. It defined among all bases of activities of diplomats accredited at Communities. This kind of activities of international institutions representatives can be defined as paradiplomacy. First of all, it involves activities of non-governmental organisations and transnational corporations or substate units, such as Swiss cantons, German lands, Euroregions. They locate their representatives at the EU to allow them for more efficient influencing decisions making process within its framework. Ratification of the Treaty of Lisbon introduces new phenomenon in the model of diplomacy. Established in year 1999 within the framework of II pillar of the EU, the post of the High Representative for the Common Foreign and Security Policy - which face was Javier Solana, stopped its existence. It was replaced by the Commissioner Catherine Ashton, head of the EU Ministry of Foreign Affairs. ${ }^{14}$ This is unusually important occasion and challenge for researchers of international law and international relations science.

So how should we define in this new reality, more accurately than the above-mentioned definition, postmodern world's diplomacy? J. Melissen thinks, that modern „diplomacy can be defined as a mechanism of representation, communication and negotiation, through which states and other international actors conduct own businesses." 15 However, more justified

14 British C. Ashton is part of 27-person European Commission, symbolising EU government. New European Commission has 25 commissioners and President J.M. Barroso and EU Minister of Foreign Affairs C. Ashton.

15 Quotation after B. Surmacz, Dyplomacja w późno westfalskim ładzie międzynarodowym, [in:] M. Pietraś and K. Marzęda (ed.) Późnowestfalski lad międzynarodowy, Lublin 2008, p. 247. 
would be definition of modern diplomacy as dynamic and historically changeable area of international relations and world politics, symbolising deep process of vertical and horizontal transformation of the international system, as well as methods and means at disposal of institutions and their representatives entitled to it. Traditionally, functions of diplomacy consisting in three words: observer - negocier - proteger become entitlements attributed today not only to states, but more and more numerous nonterritorial subjects.

However, does this type of activities and functions representing reasons and interests of non-territorial subjects suit the canon of classically understood diplomacy? Here, a doubt appears. It seems, that if it's about changes occurring in modern world, it is more justified to talk about three schools and three approaches to the diplomacy, as S. Murray suggests in the Consolidating the Gains Made In Diplomacy Studies. A Taxonomy, or as S. Strange proposes about three dimensions of diplomacy.

The first one is created by traditional diplomacy including international relations. The second is created by state-corporations relations, the third one - intercorporational diplomacy ${ }^{16}$. If we accept one of proposed classifying models, the change of forms of activities included in functions of negotiator and advocate of their reasons and interests becomes not so much cognitively significant, but the problem of responsibility for effects of their activities in the global, regional, and local dimension. In this context, interesting tone has J. Melissen's proposition to define diplomacy "as a mechanism of representation, communication and negotiation, by which states and other international actors conduct their own businesses."17 However, if we agree with intentions in the above-proposed extensive definition of diplomacy, there appears the problem of relation of interests and reasons of subjects, on behalf of which these new diplomats realise

16 S. Murray, Consolidating the Gains Made In Diplomacy Studies. A Taxonomy, "International Studies Perspectives" 2008, No. 9, p. 22, S. Strange, States, Firms and Diplomacy, "International Affairs" 1992, No. 1, pp. 6-8.

17 Quotation after B. Surmacz, Dyplomacja w późno westfalskim ładzie międzynarodowym, [in:] M. Pietraś and K. Marzęda (ed.) Późnowestfalski lad międzynarodowy, Lublin 2008, p. 247. 
their functions and international environment, for which their activity is not indifferent. It isn't indifferent also in relations on the horizontal level, that is state with state, and in state-non-state relations it gets special meaning. First of all, because states are obligated by the Convention of year 1961 and other international law acts regulating issues of state's responsibility for actions of its representatives and their effects. One can't say the same about non-state actors. It seems that they don't feel always obligated by the message of Hans Jonas, exquisite German ethicist, philosopher and religious studies researcher, in which he recommends to "Act in such a way, that effects of your actions enable durability of real human life on Earth" or "Act in such a way, that effects of your actions wouldn't shatter future opportunity of such a life."18

Diplomats represent a state, and they receive the mandate to perform their function from a government, so they are responsible to it and a society for the quality of their diplomatic service, its effectiveness. Acting for the benefit of transnational corporation creates new type of diplomat and diplomacy, in which this ethical directive is not always perceived. As J. Kleiner writes, such a diplomat is more a representative of „international public service”, and its task differs from tasks given to classic diplomats. Moreover, diplomacy of non-state actors takes today the form differing from historically shaped by Westphalian pattern system of codes of behaviour and their consequences. In practice it can mean their greater freedom of action and other kind of responsibility for consequences of their actions. This type of diplomatic activity is managed by different logic (selfish) and different motivations. While for classic diplomacy discretion, trust and (at least theoretically) openness for compromises are still better, public diplomacy functions better in the light of cameras, specific political show.

18 Quotation after M. Dobrosielski, Etyka a polityka i dyplomacja, [in:] M. Wilk (ed.), Dyplomacja, Łódź 2002, p. 266, see also B.I. Popow, Sowremiennaja diplomatija. Teoria i praktyka, Moscow 2000, p. 12 and other. 


\section{WHAT SPOILS THE IMAGE OF MODERN DIPLOMACY?}

In various world cultural circles in the past one could also meet different codes of behaviour of states and their representatives in capitals of sovereigns. However, they didn't have such a world-threatening message. Civilisation of death, how one often calls the epoch, in which we live, embraces also codes of international behaviour, which certainly differ from those described in textbooks on diplomacy, diplomatic protocol, and etiquette. What suits them, what is the factor, which took diplomacy out of salons to medially open space? Answers to this question should be searched for rather in the appearance of spectacular mass-media and their easy accessibility, radical breakthrough in mechanisation of a way of communication, in use of - as opposed to classic diplomacy - non-verbal mass-media ${ }^{19}$.

These features of the postmodern world had to leave some track on understanding the diplomacy, applied methods and forms of activities, functions and statements, for which it appeared. In very simplified forms diplomacy had appeared already in tribal structures, it experienced its peak in the antiquity, just to mention Byzantine splendour, then it was forming its image and legal-international regulations in the phase of Westphalian order, but today it is entrapped by the postmodernity. Admittedly, as R. Frelek writes, „Its principles and ways of actions haven't changed a lot since the ancient times, just its unusually colourful ceremonial became simplified, and together with new means of communication diplomatic communication became faster" 20 , though, diplomacy in the postmodern world is changing. Today it is difficult to imagine, that any state's leader sends their adversary diplomatic note in the exotic, as for modern times, form, just like the Scythians ruler, Idantiros, did for Persian ruler, Darius. The note included a mail consisting bird, frog, mouse and five arrows. In verbalised formula and interpretation of court magician of Persian ruler,

\footnotetext{
19 Such new actors are e.g. media, which present problems of modern world via mass communicators, for examples wars with their tragedy and cruelty, private stations influencing its audience, as Al Jazeera.

20 R. Frelek, Dzieje dyplomacji, Toruń 2006, p. 6.
} 
symbols of bird, frog, mouse and arrows meant the ultimatum of surrender put to Persians, although in the exotic form ${ }^{21}$.

There is a lot of similar examples of non-verbal communication in important state issues in the history of diplomacy. However, always state's potential, level of civilisation development, cultural heritage, social and political systems, geopolitical position, and what's more important, interests, aspirations, which should be secured, have been deciding on the diplomacy of various historical epochs, on its shape, splendour of diplomats, power of diplomacy, etc. There was no interdependence and globalisation, modern means of communications, their accessibility and power of destruction, which they often have. They leave their stamp on the process of formulating and realising state's interest and its ability to yielding or surrendering to influences of the international environment. Generally, strong countries strive for shaping an environment suitable for their interests and expectations through foreign policy and diplomacy, while weaker countries fall under its influence, adapting their foreign policy to its expectations and signals. The first one should be defined as the activist model of foreign policy, the second one as the model of passivist policy and respectively the model of state passive behaviour strategies and model of active or creative strategy ${ }^{22}$. In each of them a diplomat, as a representative of sending country in hosting country, may play special role. So diplomacy in the postmodern world symbolises not only extension of the circle of international relations participants, but first of all methods and forms of actions, sets of instruments, which they have at their disposal, as well as easiness and accessibility to a receiver. In turn, antidiplomacy becomes the symbol of international activity of non-territorially organised subjects, which behaviour is opposite to the essence, message of diplomacy, its functions and means, which they use, being suitable for the James Der Derian's model of "antidiplomacy." They made violence, fear and threat basic tools of communication and representation of their interests. These

21 "Persians, if you don't become birds and fly into the sky, or change into mice and hide underground, or in the form of frog jump into swamps - you won't come back home killed by these arrows". After: C. Goliszewski, Wojna w wojnie, p. 49.

22 T. Łoś - Nowak, Stosunki Międzynarodowe. Teorie - systemy - uczestnicy, Wrocław 2006, p. 280 and other. 
first ones suit the paradigm of neo-diplomacy. The last ones suit the paradigm of antidiplomacy.

Neo-diplomacy differs basically from traditional diplomacy - this traditional one is in direct relation with state's foreign policy, it is an instrument allowing state for realising its foreign policy. "Diplomacy is a synonym and symbol of art and knowledge," which is to serve a state ${ }^{23}$, while diplomatic activity of non-state subjects realise purposes and interests of groups, which they represent, often these are selfish interests. Some exceptions are organisations and some non-governmental organisations. To a higher degree they suit strategies of state foreign policy, create common ground of fulfilling their state interests.

\section{DIFFICULT COEXISTENCE OF NEO - AND ANTIDIPLOMACY}

Trying to define significant premises of evolution of classic diplomacy, one should pay attention first of all to the specificity of international environment of what we define as the postmodern world. To a high degree it generates factors, which shape modern diplomacy anew. First, as I mentioned above, these are new actors of world politics, second, new kinds of relations of world politics actors, third, levels and kinds of dependences presented between them, finally, their relevance. In various historical periods diplomacy symbolised interests of various actors. The appearance of a state in the edition of subject with national sovereign gave the diplomacy a dimension of international relations and ways of communication. The appearance of non-territorial participants not only enlarged objective arena of world politics, but first of all changed significantly levels and structure of relations between them. In case of states they were arranged horizontally, what wasn't indifferent for evolution of diplomatic forms. The appearance of non-territorial participants gave relations between them the vertical dimension. To some degree it was changing the sense and p. 327 .

3 J. Kleiner, The Inertia of Diplomacy, "Diplomacy and Statecraft” 2008, vol. 19, 
essence of traditional diplomacy. It should also be emphasised that the oldest historical records about diplomatic missions indicate their decidedly mythical and sacral context. More rationalised actions have been exposed only since the Renaissance. Mystical serving deities or later rulers and kinds was replaced by raison d'être in the horizontal arrangement - sovereign country with sovereign country - in accordance with par in parem non habet imperium formula. In the 20th century, in the phase of deep changes in the international system, stratification of international relations subjects, their new representatives and reasons, on the one hand postmodern diplomacy functions in its classic way, on the other hand we have "neo-diplomacy", symbolising new codes of behaviour, new institutional solutions and legal regulations, new values, objectives and means of actions. Its negation becomes "antidiplomacy". It is the sign of developing process of deep stratification of parties - participants of international relations and separation of their reasons and interests. These actual factors influence deeply the form and means of appearance of modern diplomacy, and the one, which is often called antidiplomacy ${ }^{24}$.

It symbolises the process of verticalisation of relations between new and old subjects of international relations. It exposes also their frequently contradictory reasons and interests, calls for radical transformation of international order, easier and quicker reaches for impolitic means and methods, considering diplomatic means as little effective. It also easier radicalises and verbalises its expectations. Often it becomes more mystical, what reminds its original roots: diplomacy of pharaohs, biblical diplomacy, this with Greek amphictyonis and symmachias.

The appearance, next to a state, of non-territorial international participants with different construction, philosophy of actions, different objectives - often contradictory with state's raison d'être, so one of the most important factors influencing parcaptitably objective relations of relations between "representatives" of territorial and non-territorial subjects. This seems to certainly influence classic diplomacy, enriching it with new functions, institutional constructions, at last legal regulations. Thus, 1992.

24 J. Der Derian, Antidiplomacy: Spies, Speed, Terror and War, Oxford Blackwell 
not replacing classic diplomacy, there develops neo-diplomacy, symbol of the postmodern world, with its deep vertical and horizontal transformations. Next to these two types of diplomacy, there seems to function completely new subject representing interests, ambitions, and expectations of actors, which aren't obligated by international conventions, recognised norms and regimes of behaviour, using forcible methods and means, often brutalising international relations. It is antidiplomacy.

The originality of neo-diplomacy and its specific revolutionariness consists in exposing the unity between people and political communities, indicating common values of the international society and deep changes occurring in the international system, especially abatement of the centric model. While not rejecting the output of classic diplomacy, it seems to indicate, that forms of international contacts, worked out by the humanity in its long history, aren't always able to quickly react in terms of great dynamism of the international environment and various, often contradictory, expectations of the international society. So one should enrich them by new instrumentarium and means of communication. It's because of two essential reasons. First, because more and more significant becomes the process of moving centre of gravity in the analysis of actions and influences in the international relations from the state-centric level, so in the arrangement state-non-territorial subjects (social, political, economic communities and organisations) from horizontal to vertical. They are present in world politics just so strongly as states. Second, due to revolutionary changes in mass-media, means of communication, almost immediate availability of signals sent by diplomats.

This multiplication of actors participating in world politics forced changes in forms of international contacts, means and methods of solving problems important for each of them, abating the exclusivity of traditional diplomacy, for the benefit of neo-diplomacy, conference, public, local and transboundary, personal contact diplomacy and other ${ }^{25}$. Paradoxically, the factor that abates, degenerates and often "replaces" classic diplomacy is

25 Such an example became transmissions of talks of J.F. Kennedy with N. Khrushchev during the Cuban crisis in 1962, visit of A. Sadat in 1977 in Jerusalem, to Middle Eastern crisis. 
the accessibility of newest means of communication, massivity and spectacularism of media, being a denial of the essence of diplomacy.

Development of communication techniques, media attractiveness of diplomacy, new mass-media, being at disposal of not only embassies and diplomatic posts, but also non-territorial actors, change the postmodern diplomacy, its character, essence, forms and means at disposal of its representatives, whether we like it or not. Just like in year 1815 during the Congress of Vienna where appeared diplomatic protocol, motivated by the need of putting in order principles of negotiations, validity of kings and emperors' plenipotentiaries, mechanisms of precedence, etc., in the 21st century needs of extending the circle of subjects entitled to specifically understood diplomatic service is the natural course of events. As the history shows, this function of representing interests of various "international" subjects changes just like the world changes. Just like each epoch has its wars, diplomacy has specific forms of appearance. There remains a question, apparently rhetorical: what is permanent and unchanging in neodiplomacy and antidiplomacy, what seems to be this signum temporis at the turn of centuries and how can these changes be used to more full representation of stratificated interests of the international society?

In short, one can say that existence of state as a sovereign actor ${ }^{26}$ implies the importance of classic diplomacy, legal-international regulations, conventions concerning broadly understood diplomatic service. It still is important field of actions for a state. However, on the other hand, for at least 50 years next to states ${ }^{27}$ on the international arena and in world politics, there have stayed non-territorial subjects, often influencing international relations with power and possibilities greater than potential of many countries. Their rise and activities in the area of international relations and world politics were dictated by the need of strengthening or facilitating contacts between countries, "restoring patency and abating instruments of more efficient flow of information, goods and services, as

\footnotetext{
26 I live with full awareness of complicated discussion on sovereignty and future of national states in its current edition, recommending rich literature.

27 I pass over also interesting discussion on changes in modern states to new phenomena, as quasi-states, territorial nations, mini states, etc., recommending quite rich literature available also on the Polish market.
} 
well as mutual protection."28 Over time, next to governmental organisations, presence in the international system was manifested by social groups, social-cultural, civilisation-economic, ecological movements, as for example Greenpeace, Globalists, Anti-globalists or Alter-globalists, transboundary corporations. Especially in recent years presence in the international relations was violently manifested by religious sects, but also more and more often by terrorist organisations with decidedly political program and goals of actions. They all live in their own rhythm, generate own interests, conduct own international policy. However, motivations of their activity in the international relations are certainly different from those represented by states. In case of many non-state participants of international relations, there is being built trust between them, throwing bridges, integrating societies around common values, creating kinds of "collective self", to which states, selfish from their nature, aren't able. However, amongst them are also subjects rejecting a limie values, which were fundaments of modern democracies, national countries, and democracy instead of anarchy ${ }^{29}$. The way, in which they do it, is to a high degree a derivative of the culture of behaviours, which dominated the postmodern system of international relations, leaving its stamp on "the image" of modern diplomacy.

In the history of international relations there were formed three dominating cultures of anarchy: Hobbes's, Locke's and Kant's. Each of them can have assigned specific systems of valuating in relations between participants, various strategies of conducted external policy, various attributes of reasons and interests' bearers in the international environment, various kinds of anarchisation of the international system, finally models of diplomacy and diplomatic principles, preferences, etc. One can easily infix them in the James Der Derian's paradigm of diplomacy, more precisely genealogy of diplomacy, presented widely in book entitled On Diplomacy: Genealogy of Western Estrangement ${ }^{30}$. Omitting details of historical models, which Der Derian reconstructs in the process of getting to know

28 T. Łoś - Nowak, Stosunki Międzynarodowe. Teorie - Systemy - Uczestnicy, Wrocław 2006, p. 321.

29 More: A. Eban, Diplomacy for the Next Century, London 1998.

30 J. Der Derian, On Diplomacy: A Genealogy of Western Estrangement, Oxford, 1987. 
diplomacy and discovering its essence, which he sees in mediations (their various forms - author's note), it is worth to pay attention to one of principal for it premises of evolution of forms and methods used in diplomacy. It is the alienation (exclusion) of various social groups from areas of social, economic, political etc. life. The formula of alienation is understood by Der Derian also as a state of separation of sovereign country from another sovereign country or individual and God, imposing the need of going between them. States of exclusion and separation require the same external subjects connecting with God, ruler or state. The way of performing connecting functions depends actually on the culture of anarchy in various historical periods. Once these are diplomatic methods, but also not diplomatic, like violence, force, terror. Their choice depends on situation, status of alienated, power of their pretensions. So the formula of alienation is the leading power of historical development of diplomacy and humanity, Der Derian claims ${ }^{31}$. From the oldest mythical (mytho-diplomacy) saying about the need of agency between God and a human being, through Machiavellian paradigm of protodiplomacy symbolising clear Westphalian model of diplomacy, Reader is led to the phase of antidiplomacy symbolising the period of revolutionary terror of the eighteenth-century France and revolutionary Russia in the beginning of the 20th century. In that two periods social classes excluded from social and political systems of bourgeois France and tsarist Russia became powerful. In both cases revolutionary character of powers going between Russian tsar and French king, deeps contradiction of reasons and interests of rulers and excluded citizens, hate and willingness of revenge were dictating methods and means of fighting for own reasons and interests. It was burying down classic canons of Westphalian diplomacy, introducing violence, intrigue, trick, it was becoming a symbol of antidiplomacy, infixing itself to Hobbes's culture of anarchy.

Second half of the 20th century, with rapid explosion of number of territorial and non-territorial participants of international relations, with deep social and cultural divisions inside sovereign countries, with radicalising attitudes of those new subjects of socio-economic, socio-cultural

31 Ibidem, p. 42. 
life, with unseen easiness of their communication, with revolution occurring in mass-media, making them easily accessible "material" to manipulate the image, mood, scale of problems, changed diplomacy again, introducing next to the postmodern model of neo-diplomacy, forcible methods and means of "going between" stratified society and power of selfish states, between societies of various cultures, religions, values and dominated model of territorial state, etc. In many cases this is decidedly dangerous change, because it suits more Hobbes's philosophy of politics, than behaviour appropriate for Locke's or Kant's culture of anarchy.

Can this process of anarchisation and spoiling diplomacy be stopped? This question doesn't have simple answer. One can assume, that transition to Kant's culture of anarchy is possible, but it isn't historical necessity. Time can simply deepen bad norms, not necessarily creating new, good ones. The antidiplomacy of non-territorial subjects, especially terrorist organisations symbolising the biggest threat for international security, is fastered - like never before - by the newest technique of communication and media transmission. Often methods applied by them become more dangerous tool of political messaging, than the most sophisticated worked out diplomatic negotiations. What's even worse, they are used not only by organisations with terrorist orientation, but also by states. These are not countries considered as "bandit", but also these with established democratic system and long tradition of classic diplomacy. If terrorism becomes a kind of war conducted with different means and a tool giving power, which enables to accomplish political goals, if an image becomes stronger argument, than long negotiations, if professionalism starts to give its place to diplomatic theatre, maybe post-Westphalian diplomacy is no longer needed?

It doesn't seem to be like that. At the most it is enriched and supplemented by new mechanisms often supposed to improve its efficiency. It concerns states and non-territorial subjects, such as transnational and non-governmental organisations, social or cultural groups with specific level of organisation, for which diplomatic methods and means of solving problems have decidedly positive value. However, traditional diplomacy and neo-diplomacy face a challenge of terrorist organisations, reaching for forcible methods and means, rejecting dialogue, mediations or other 
forms of peaceful going between parties divided by the wall of contradictory interests. There is hope, though, that if highly developed countries, to reasonable degree, start political and diplomatic dialogue with many organisations staying beyond any legal and institutional system regulating broadly understood diplomatic law, organisations defending Kurds, Palestinians, Tupamaros or Monteneros, the poorest world countries and their citizens, groups of Alter-globalists and similar will leave radicalism, which makes impossible a dialogue based on respecting principles valid in diplomatic practice. 